\title{
Utilization of Coffee Skin Fiber as Potential Sources of Reducing Sugar by Means of Enzymatic Hydrolysis
}

\author{
Noor Ariefandie Febrianto ${ }^{1 *}$, Nafiul Amri ${ }^{2)}$, and Wiwik Siti Windrati ${ }^{2)}$ \\ ${ }^{1)}$ Indonesian Coffee and Cocoa Research Institute, Jl. PB Sudirman No. 90, Jember 68118, Indonesia \\ ${ }^{2}$ Faculty of Agricultural Technology, Jember University, Jl. Kalimantan No. 37, Jember 68121, Indonesia \\ ${ }^{*}$ Corresponding author: ariefandie@iccri.net \\ Received: 28 September 2018 / Accepted: 20 October 2018
}

\begin{abstract}
Coffee skin and pulp compromised almost $50-60 \%$ of coffee bean, in which most of them will be turned to waste during coffee processing. Until now, the utilization of coffe skin is still limited to low-value products such as compost, fertilizer and feed. Further utilization of coffee skin has been reported by means of chemical or enzymatic degradation of its structure, whether intended to improve the digestibility of feed, improving the nutritional properties or as potential media of fermentation. This research aimed to study the potential of coffee skin fiber to be used as the source of reducing sugar using acid cellulase enzyme and determine the optimum process of hydrolysis of the coffee skin fiber. Delignification using base was carried out prior to enzymatic hydrolysis. Small scale enzymatic hydrolysis was carried out utilizing Sqzyme CSP, an acid cellulase enzyme in various units $(200,400$, and 800 units) for 12 and 24 hours. The evaluation of the hydrolysis performance was carried out by total and reducing sugar analysis followed by the quantification using liquid chromatography-mass specthrometer method. The total sugar content was ranged from $0.149 \mathrm{mg} / \mathrm{mL}$ to $0.584 \mathrm{mg} / \mathrm{mL}$ whereas the reducing sugar content was ranged from $0.013 \mathrm{mg} / \mathrm{mL}$ to $0.114 \mathrm{mg}$ / $\mathrm{mL}$ with the highest production of sugar was obtained using 800 unit of enzyme and incubated for 24 hours. The glucose content was $36,1 \mathrm{ppm}$ or compromised around $31.57 \%$ of total reducing sugar produced in the best treatment. The study shows that the enzyme used in this experiment could be used in first stage of coffee skin fiber hydrolysis process to obtain abundant substrat for potential subsequent process.
\end{abstract}

Keywords: Belignification, cellulase, lignin, glucose, oligosaccharides

\section{INTRODUCTION}

Coffee skin accounted for almost two-fifth part of coffee bean and combined to the pulp, it is accounted for almost $60 \%$ of coffe bean (Gathuo et al., 1991). Musatto et al. (2011) and Nabais et al. (2008) stated that during coffee beans processing, large amount of by-products are generated, in which Berlitz et al. (2009) and Esquivel \& Jimenez (2012) mentioned that approximately
$50 \%$ of the coffee fruit turn to waste during the production of green coffee beans. The coffee husk itself mostly constituted by fiber, protein, sugar, pectin and tannin (Wilson, 1985). Until now, there are still limited number of effort to utilize coffee skin/husk, mostly are under-utilized as fertilizer, feed and compost (Richana, 2002). Murthy \& Naidu (2012) previously mentioned that coffee husk can be utilized in mould, yeast and enzyme production as substrate due to its high amount 
of fermentable sugars. Arrizon et al. (2012) further utilize the fermentable sugar obtained from the hydrolysis to produce bioethanol. Similar studies had also been reported by Sampaio et al. (2013), and Gouvea et al. (2009).

High lignin content has been noticed as important aspect in coffee husk enzymatic hydrolysis. Taherzadeh et al. (2007) previously mentioned that lignin-coated cellulose is harder to breakdown and take longer time to be hydrolyzed. Delignification process is crucial in hydrolizing plant tissues due to the ability of lignin to reduce the accessibility of cellulose to enzymes (Wyman et al., 2005). The removal of lignin can be carried out using dillute acid pre-treatment at higher temperatures which led to shrinking and agglomeration of the lignin (Ooshima et al., 1990). Further, Michalowicz et al. (1991) and Selig et al. (2007) also mentioned that the dillute acid pre-treatment could resulted in lignin melting and its relocation that led to cellulase ability to access the cellulose. Delignification can also be carried out using base such as $\mathrm{NaOH}$ and $\mathrm{Ca}(\mathrm{OH})_{2}$, which will attack and breakdown the lignin structure, crystalline and amorf part of lignocellulose (Gunam et al., 2011)

Acid cellulase enzyme has widely applied in hydrolysis of cellulose. It has been used in the hydrolysis of palm oil empty branches (Caecilia, 2015) and corncob (Ouyang et al., 2009). Further, the increasing concern in enzymatic hydrolysis is occured due to the cheaper price of the enzyme as its increasing share of world's industial enzyme market (Zhang \& Zhang, 2013). However, the cost of cellulose hydrolysis is still considered high due to its inefficiency to degrade pretreated lignocellulosic material. Thus, the combination of process is needed to achieve optimum hydrolysis process.

Three main types of cellulase enzymes are often to be used to achieve complete cellulose hydrolysis, namely endocellulase (endoglucanases EC 3.2.1.4), exocellulase (exoglucanase EC 3.2.1.91) and $\beta$-glucosidase (cellobiase EC 3.2.1.21). Endoglucanase randomly cut $\beta$-1,4-bonds of cellulose chains, generating new ends. Further, it also bind and cleave the cellulose chain to generate glucose, soluble cellodextins or insoluble cellulose fragment. Some of endoglucanases have an ability to generate other product such as cellobiose or longer cyclodextrins (Cohen et al., 2005; Li \& Wilson, 2008; Mejia-Castillo et al., 2008; Parsiegla et al., 2008). This research aimed to study the potential of coffee skin fiber to be used as the source of reducing sugar using acid cellulase enzyme and determine the optimum process of hydrolysis of the coffee husk.

\section{MATERIALS AND METHODS}

Fresh coffee skin was obtained from coffee farmer in Sumberwringin, Bondowoso District. Coffee skin was collected during depulping process of Arabica coffee cherry, and was then immediately freezed $\left(-20^{\circ} \mathrm{C}\right)$ until used. Hydrolysis agent of the acid cellulase enzyme (Sqzyme CSP) was purchased from Suntaq International Ltd. with the enzyme activity was 10.000 units/g.

The experiment was carried out utilizing factorial complete randomized design with two factors such as duration of hydrolysis (time, hours) and enzyme units (units), in which duration of hydrolysis was divided into 2 levels (12 and 24 hours) and 3 levels of the enzyme units (200, 400, and 800 units).

Preparation of coffee skin fiber (CSF) was carried out to obtain pure delignified fiber of the coffee skin. The preparation was started with delignification process to obtain lignin-free CSF which was carried out based on alkaline hydrolisis method. Crushed coffee skin was mixed with Sodium hydroxide $(\mathrm{NaOH}) 0.1 \mathrm{M}$ with the ratio of $1: 20(\mathrm{~b} / \mathrm{v})$. The mixture was then heated in boiling water 
for 3 minutes. After cooled at room temperature, the mixture was then filtered and washed using distilled water as much as $3000 \mathrm{~mL}$. The precipitate obtained was then referred as delignified CSF (DCSF).

Small scale enzymatic hydrolysis was carried out utilizing Sqzyme CSP, an acid cellulase enzyme. As much as $0.5 \mathrm{~g}$ of DCSF was dilluted in distilled water and adjusted to $\mathrm{pH} 5.5$ using citrate buffer. The mixture was then pre-incubated in using shaker water bath at $55^{\circ} \mathrm{C}$ for $3-5$ minutes and then added with enzyme with certain units (200, 400 , and 800 units). The hydrolysis process was carried out at $55^{\circ} \mathrm{C}$ for 24 and 48 hours based on the experimental design. After certain time of hydrolysis process was fulfilled, the process was then terminated by inactivated the enzyme at $70^{\circ} \mathrm{C}$ for 15 minutes. The hydrolysate solution was then separated wit its precipitate by means of centrifugation at 3500 RPM for 20 minutes. The solution obtained was then referred as sugar hydrolysate solution (SHS). The SHS was then subjected into total sugar, reducing sugar and polymerization degree analysis.

Total sugar analysis was carried out based on the method of Dubois (1956) by means of strong acid hydrolysis. Twenty mililiter of SHS was added with $0.5 \mathrm{~mL}$ phenol reagent $(5 \%)$ and then vortexed. As much as 2.5 sulfuric acid $\left(\mathrm{H}_{2} \mathrm{SO}_{4}\right) 98 \%$ was then added quickly and vortexed, then cooled at room temperature for 2 minutes. The solution was then subjected to absorbance measurement spectrophotometrically at wavelength $490 \mathrm{~nm}$ (Perkin Elmer Lambda 35 UV/Vis Spectrophotometer). The content of sugar was measured by comparing the absorbance of the samples with the absorbance of standard glucose solution and referred as $\mathrm{mg}$ sugar/mL SHS.

Reducing sugar was analysed based on Dinitrosalicylic acid (DNS) reaction. DNS reagent was made by dilluting $10 \mathrm{~g} \mathrm{NaOH}$, $0.5 \mathrm{~g} \mathrm{Na}_{2} \mathrm{SO}_{4}$ (sodium sulfate), and $\mathrm{KNaC}_{4} \mathrm{H}_{4} \mathrm{O}_{6} \cdot 4 \mathrm{H}_{2} \mathrm{O}$ (kalium sodium tartrate) in $1 \mathrm{~L}$ distilled water. The solution was then added with $10 \mathrm{~g}$ of DNS until perfectly dissolved. As much as $20 \mathrm{ml}$ of SHS was mixed with $1 \mathrm{~mL}$ of DNS and then heated at $100^{\circ} \mathrm{C}$ for 15 minutes. The heated solution was then cooled at room temperature for 5 minutes and then measured its absorbance at $540 \mathrm{~nm}$ (Perkin Elmer Lambda $35 \mathrm{UV} /$ Vis Spectrophotometer). The content of reducing sugar was measured by comparing the absorbance of the samples with the absorbance of standard glucose solution and referred as $\mathrm{mg}$ reducing sugar/mL SHS.

Identification of glucose occurrence in SHS was carried out utilizing Liquid Chromatography-Mass Spectrometer. Shimadzu LC-MS 2020 (Shimadzu, Japan) equipped with Waters C 18 column (Waters, USA) was set at column temperature of $40^{\circ} \mathrm{C}$ and flow rate $1 \mathrm{~mL} / \mathrm{min}$. The detection was done using mass spectrometry, whereas the quantification was done using glucose standard.

Data analysis was performed using General Linear Model (GLM) followed by Duncan MRT (multiple range test) post- hoc analysis performed on the statistical package for social science (SPSS) software version 17.0 (IBM Corporation, Armonk, New York, USA). The statistical analyses were performed at 5\% significance level. Descriptive analysis using surface and contour plot was done using Sigmaplot ver 12.3 (Systat Software, Inc).

\section{RESULTS AND DISCUSSION}

Total sugar content of coffee skin fiber's hydrolysate solution is presented in Figure 1. The total sugar content was ranged from $0.149 \mathrm{mg} / \mathrm{mL}$ to $0.584 \mathrm{mg} / \mathrm{mL}$ with the highest production of sugar was obtained using 800 
unit of enzyme and incubated for 24 hours. Analysis of variance on the total sugar content of the SHS resulted in the conclusion that the effect of time of hydrolysis was insignificant $(\mathrm{p} \geq 0.05)$, thus the total sugar produced was not significantly different between 12 and 24 hours using the same unit of enzyme. However, the unit of enzyme used was a significant factor to the production of sugar from CSF. It was also evaluated that the increase in enzyme unit used was linear to the total sugar obtained, in which two-fold increase of enzyme unit produced in almost two-fold increase of total sugar produced. It was in agreem ent with the result of Ouyang et al. (2009) which mentioned that the yield of corncob hydrolysate was increasing as the increase of cellulase enzyme utilized.
High content of sugar in hydrolysate solution indicated that there were carbohydrates released into the solution which confirmed that there were a hydrolysis of cellulose occured. According to Gunarto (2009), acid cellulase enzyme hydrolize the $\beta-1,4$ glycocidic bond in cellulose resulting in oligosaccharide or glucose. However, it is also stated that the result obtained from hydrolysis directly correlated with the type of enzymes used, wheter it was endocellulase, exocellu-lases or cellobiases. The enzyme used in this experiement was an acid endocellulase enzyme (EC 3.2.1.4) which able to break the non-covalent interactions present in the crystalline structure of cellulose. This specific cleave in internal bonds of cellulose will create new chain ends, in which it could be monomer or oligomer (Enari \&

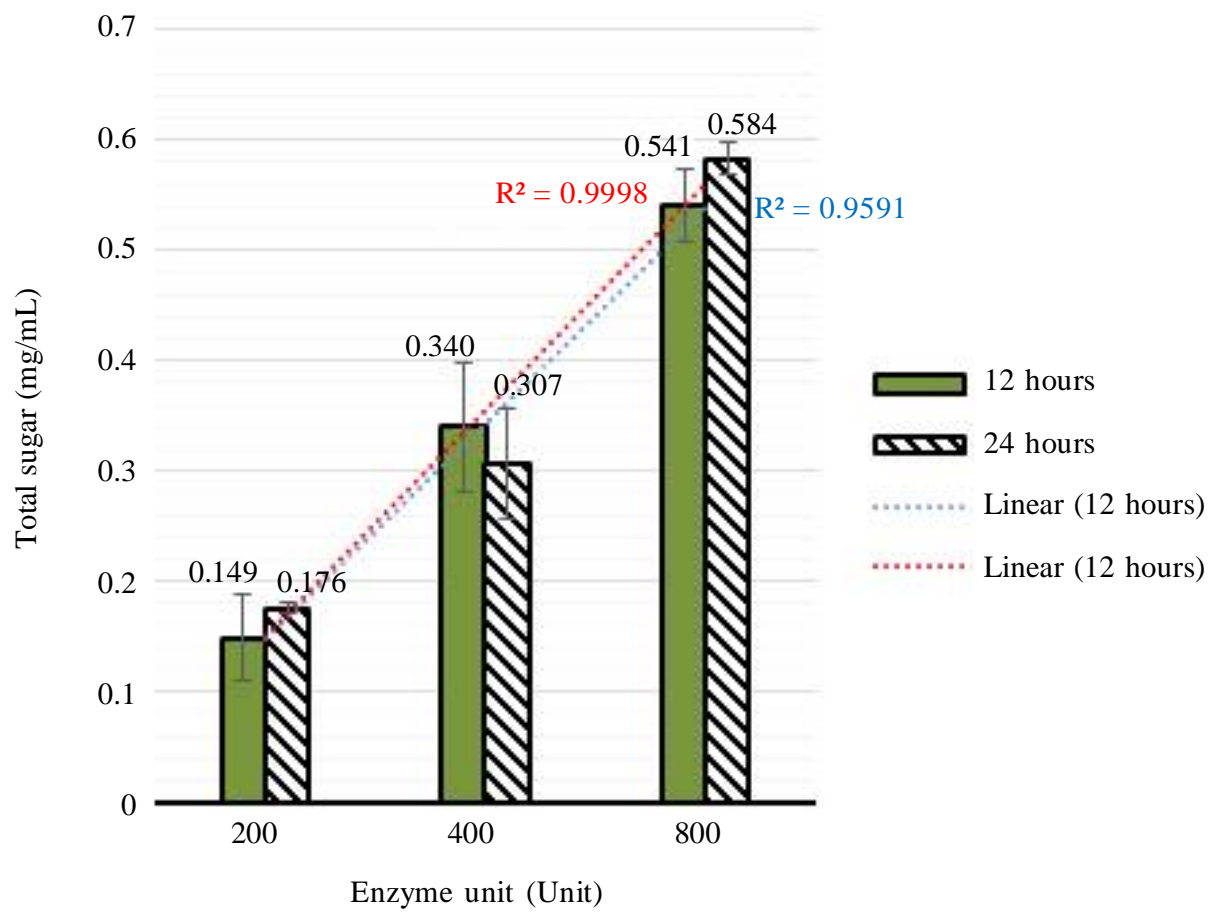

Figure 1. Total sugar content of coffee skin fiber's hydrolysate solution 
Fogarty, 1983). Since the hydrolysis of cellulose by enzyme significantly related to its active site requirement, the yield obtained is currently lower to that of acid hydrolysis which could hydrolyze randomly and extensively at any hydrolizable bonds in term of total soluble sugar obtained as mentioned previously by Wardhana (2014).

On the other hand, the reducing sugar obtained from the hydrolysis process was presented in Figure 2. The reducing sugar content was ranged from $0.013 \mathrm{mg} / \mathrm{mL}$ to $0.114 \mathrm{mg} / \mathrm{mL}$ following the same linear trend to that of total sugar content. However, there was a significant effect of the interraction time and enzyme unit on the concentration of reducing sugar obtained. It was evaluated that the treatment with longest hydrolysis time using highest unit of enzymes could produce highest reducing sugars concentration $(0.114$ $\mathrm{mg} / \mathrm{ml}$ ). It was in agreement with the result of Ouyang et al. (2009) which mentioned that extensive interaction between enzyme and substrate during long period of incubation time often resulted in higher content of reducing sugar. The result of Ouyang et al. (2009) also suggested that the optimum time of hydrolysis varied from one substrate to another and have to be adjusted based on the sample used. However, the result obtained in this experiment was less compared to the report of Caecelia (2015) who utilized empty palm oil brunches which could produce reducing sugar up to $10.31 \mathrm{~g} / \mathrm{L}$ of hydrolysate. Since dry coffee husk contain high ligin content $(23.7-72 \% \mathrm{db})$ in par to empty palm oil brunches (24.15\%) (Bondesson, 2015; Bekalo and Reinhardt, 2009; Shenoy et al., 2011), the delignification process needed to be adjusted in order to achieve optimum

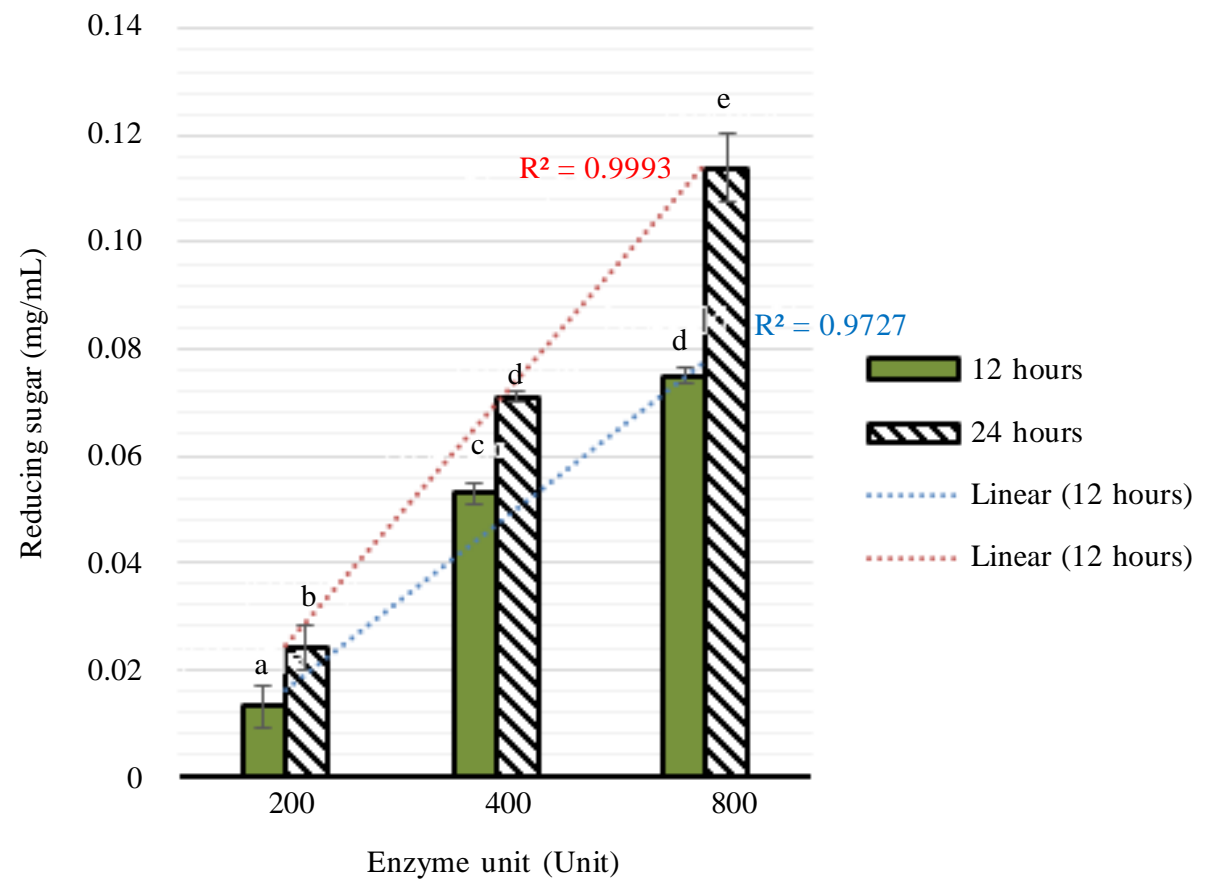

Figure 2. Total reducing sugar content of coffee skin fiber's sugar hydrolysate solution 
degradation of lignin in coffee husk prior to the hydrolysis process.

The production of the monomer of the reducing sugar is often used to measure the performance of the carbohydrate hydrolysis (Bansal, 2009). In this case, the enzymatic degradation of cellulose will endly produce the glucose monomer. Our analysis using liquid chromatography-mass specthrometer on the SHS obtained using 800 unit of enzyme and 24 hours incubation showed that the glucose content was $36.1 \mathrm{ppm}$ or around $31.57 \%$ of total reducing sugar produced in the treatment. As mentioned by Lopez et al. (2004), the hydrolysis of lignocellulose usually produce glucose, mannose and xilose or the mixture of phenolic compound. However, the cellulose itself which is a bonded chain of glucose, will mainly hydrolized into glucose when it is extensively hydrolyzed and will only produce oligosaccharides when it partly hydrolyzed (Sukumaran et al., 2005). Thus, with only $31.57 \%$ of glucose produced among all the reducing sugar evaluated, it was expected that the oligosccharides reducing sugar was a majority reducing sugars obtained which could be also including dissacharide such as cellobiose. It was concluded that the hydrolysis occured during the experiment was mainly first stage of cellulose hydrolysis, which was the act of endocellulase.

The performance of the hydrolysis could be improved by means of utilizing various type of cellulases such as exocellulase to degrade the product of endocellulase and the use of cellobiase to extensively degrade dissacharides (Bansal et al., 2009). Further, since reducing sugar only compromised around one-fifth of total sugar obtained during hydrolysis, the majority sugar liberated during hydrolysis was non-reducing sugar. Such a non-reducing polysccharide and oli-

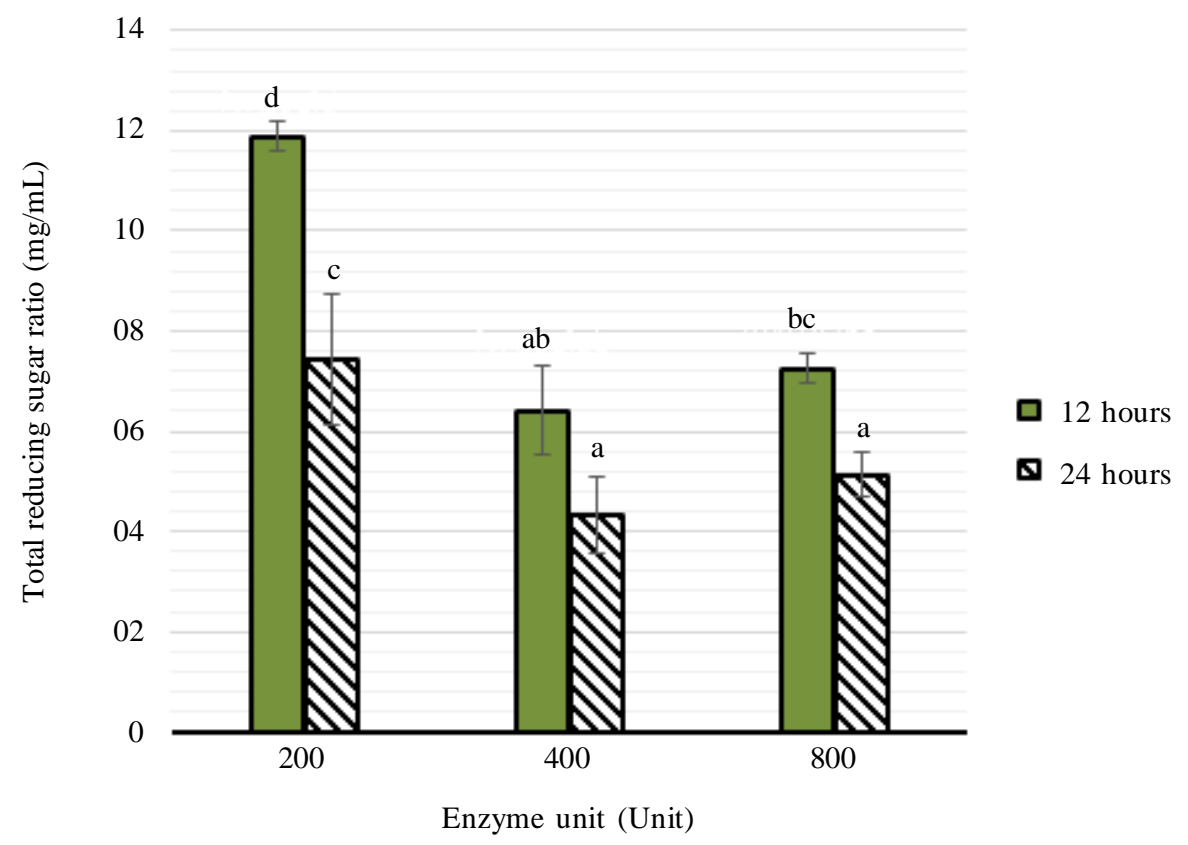

Figure 3. Ratio of total and reducing sugar content of coffee skin fiber's sugar hydrolysate solution 
gosaccharide will further need to be degraded to be able to utilized as reducing or fermentable sugar. Thus it is possible to produce higher concentration of glucose by means of utilizing multiple enzymes as reported previously by Ouyang et al. (2009) which mentioned that multi-stages hydrolysis could improve the yield of glucose from $43 \%$ to $90 \%$.

Ratio of total and reducing sugar as presented in Figure 3 showed that the ratio ranged from 4.34 to 11.89 , in which the treatment using 400 and 800 unit of enzymes for 24 hours resulted in lowest ratio, means that it produce higher proportion of reducing sugar compared to non-reducing sugar than other treatments. However, it was also noticed that eventhough the ratio was similar, the yield of total sugar and reducing sugar of the treatment using 800 unit of enzyme were far surpassed that of the 400 (Figure 1 and Figure 2). This phenomenom indicated that the lowest ratio obtained in this experiment might be the lowest possible number that the enzyme could achieved. However, this value is still higher compared to other research as reported by Ruriani et al. (2012) which mentioned that the ratio only 8-12 in corncob enzymatic hydrolysis and in par to that of Faridah et al. (2013) who reported that the ratio could be as low as 4 to 12 on acid hydrolysis of the arrowroot starch. Girisuta (2007), mentioned that the crystalline structure in coffee husk preventing the hydrolysis of cellulose. However, it is also stated that the longer time of hydrolysis should be carried out to obtain optimum hydrolysis.

\section{CONCLUSIONS}

This experiment has successfuly reveal the potency of coffee husk to be utilized by means of enzymatic hydrolysis. High proportion of glucose and reducing sugar produced open the possibility of coffee skin fiber to be utilized as fermenteation media due to its high content of fermentable sugar. However, further research should be done in optimizing the delignification process of coffee husk since current studied still not able to optimize the yield. The use of multiple enzymes can also be carried out to obtain best possible yield of fermentable sugars. It is also concluded that the enzyme used in this experiment could be used in first stage of coffee skin fiber hydrolysis process to obtain abundant substrat for subsequent process.

\section{ACKNOWLEDGEMENT}

The authors woud like to express their gratitude to the technicians in ICCRI's postharvest technology and Jember University's laboratory and also anonymous reviewers for their contribution to the perfection of this manuscript.

\section{REFERENCES}

Arrizon, J.; J.C. Mateos; G. Sandoval; B. Aguilar; J. Solis; M.G. Aguilar (2012). Bioethanol and xylitol production from different lignocellulosic hydrolysates by sequential fermentation. Journal of Food Process and Engineering, 35, 437-454.

Bansal, P.; M. Hall; M.J. Realff; J.H. Lee \& A.S. Bommarius (2009). Modelling cellulose kinetics on lignocellulosic substrates. Biotechnology Advance, $10,833-848$.

Bekalo, S.A. \& H.W. Reinhardt (2009). Fibers of coffee husk and hulls for the production of particleboard. Material Structure, 43, 1049-1060.

Belitz, H.D.; G.V. Hoioidonk \& A.P.C. Faaij (2008). Ethanol form lignocellulosic biomass techno economic performance in short midle and long term. Journal of Biomass and Bioenergy, 28, 384-410.

Bondesson, E. (2015). A Nutritional Analysis on The By-Product Coffee Husk and Its Potential Utilization In Food 
Production - A Literature Study. Uppsala, Sweden: Swedis University of Agricultural Science. BSc thesis.

Caecilia, N. (2015). Pengaruh Perlakuan Awal Basa dan Hidrolisis Enzimatis Terhadap Kadar Gula Reduksi Tandan Kosong Kelapa Sawit. Lampung: Fakultas Pertanian, Universitas Lampung. Bachelor thesis.

Cohen, R.; M.R. Suzuki, K.E. Hammel ( 2005 ). Processive endoglucanase active in crystalline cellulose hydrolysis by the brown rot basidiomycete Gloeophyllum trabeum. Applied Environmental Microbiology, 71, 2412-2417.

Dubois, M.; K.A. Gilles; J.K. Hamilton; P.A. Rebers \& F. Smith (1956). Colorimetric method for determination of sugar and related substances. Analytycal Chemistry, 28, 350-356.

Enari, T.M. \& W.M. Fogarty (1983). Microbial Enzimatic and Biotechnology. Applied Science Publisher. London, United Kingdom.

Esquivel, P. \& V.M. Jimenez (2012). Functional properties of coffee and coffee by products. Food Research International, 46, 488-495.

Faridah, N.D.; P.W. Rahayu \& M.S. Apriyadi (2013). Modifikasi pati garut (marantha arundinacea) dengan perlakuan hidrolisis asam dan siklus pemanasanpendinginan untuk menghasilkan pati resisten tipe 3. Jurnal Teknologi Industri Pertanian, 23, 61-69.

Gathuo, H.K.; V.M. Nantulya \& P.R. Gardiner (1991). Trypanosoma vivax: adaptation of two east african stocks to laboratory rodents. Journal of Protozoology, 34, 48-53.

Girisuta, B. (2007). Levulinic Acid from Lignocellulosic Biomass. Netherlands: University of Groningen. PhD thesis

Gouvea, B.M.; C. Torres; A.S. Franca; L.S. Oliveira \& E.S. Oliveira (2009). Feasibility of ethanol production from coffee husks. Biotechnology Letter, 31, 1315-1319
Gunam, I.B.W.; K. Buda \& I.M.Y.S. Guna (2011). Pengaruh perlakuan delignifikasi dengan larutan naoh dan konsentrasi substrat jerami padi terhadap produksi enzim selulase dari Aspergillus Niger Nrrl A-Ii, 264. Jurnal Biologi, 15, 55-61.

Gunarto, A. (2009). Penampilan fenotipik klon kentang g1 hasil fusi protoplas dan biji botanis yang resisten layu bakteri ralstonia solanacearum. Bionatura: Jurnal Ilmu-ilmu Hayati dan Fisik, 11, 179-194.

Li, Y. \& D.B. Wilson ( 2008 ). Chitin binding by Thermobifida fusca cellulase catalytic domains. Biotechnology \& Bioengineering, 100, 644-652

Lopez, M.L.; B. Redruello; E. Valdes; F. Moreno; J.J. Heinisch \& R. Ridicio (2004). Isocitrate lyase of the yeast Kluyveromyces lactis is subject to glucose repression but not to catabolite inactivation. Current Genetics, 44, 305-316.

Mejia-Castillo, T.; M.E. Hidalgo-Lara; L.G. Brieba \& J. Ortega-Lopez ( 2008 ). Purification, characterization and modular orga nization of a cellulose-binding protein, CBP105, a processive beta-1,4endoglucanase from Cellulomonas flavigena. Biotechnology Letter, 30, 681-687.

Michalowicz, G.; B. Toussaint \& M.R. Vignon (1991). Ultrastructural changes in poplar cell wall during steam explosion treatment. Holzforschung, 45, 175-179.

Murthy, P.S. \& M.M. Naidu (2012). Recovery of phenolic antioxidants and functional compounds from coffee industry byproducts. Food Bioprocess Technology, 5, 897-903.

Mussatto, S.I.; L.M. Carneiro; J.P.A. Silva; I.C. Roberto \& J.A. Teixeira (2011). A study on chemical constituents and sugars extraction from spent coffee grounds. Carbohydrate Polymers, 83, 368-374.

Nabais, J.M.V.; P. Nunes; P.J.M. Carrott; M.M.L. Ribeiro-Carrott; A.M. García \& M.A. Díaz-Díez (2008). Production of 
activated carbons from coffee endocarp by $\mathrm{CO} 2$ and steam activation. Fuel Processing Technology, 89, 262-268.

Ooshima, H.; D.S. Burns \& A.O. Converse (1990). Adsorption of cellulase from Trichoderma reesei on cellulose and lignaceous residue in wood pretreated by dilute sulfuric acid with explosive decompression. Biotechnology and Bioengineering Symposium, 36, 446-452.

Ouyang, J.; L. Zhenjiang; L. Xin; Y. Hanjie \& Y. Qiang (2009). Enhanced enzymatic conversion and glucose production via two-step enzymatic hydrolysis of corncob residue from xylo oligosaccharides producer's waste. Bioresources, 4, 1586-1599.

Parsiegla, G.; C. Reverbel; C. Tardif; H. Driguez \& R. Haser ( 2008 ). Structures of mutants of cellulase Cel48F of Clostridium cellulolyticum in complex with long emithiocellooligo-saccharides give rise to a new view of the substrate pathway during processive action. Journal of Molecular Biology, 375, 499-510 .

Richana (2002). Produksi dan prospek enzim xilanase dalam pengembangan bioindustri di Indonesia. Buletin Agrobio, 5, 29-36.

Ruriani, E.; A. Meryandini \& C.T. Sunarti (2011). Rekayasa proses produksi bioetanol dari tongkol jagung melalui sakarifikasi dan fermentasi secara simultan. Prooceding of Perteta. Jember, Indonesia.

Sampaio, A.; G. Dragone; M. Vilanova; J.M. Oliveira; J.A. Teixeira \& S.I. Mussatto (2013). Production, chemical characterization, and sensory profile of a novel spirit elaborated from spent coffee ground. LWT - Food Science and Technology, 54, 557-563.
Selig, M.J.; S. Viamajal; S.R. Decker; M.P. Tucker; M.E. Himmel \& T.B. Vinzant (2007). Deposition of lignin droplets produced during dilute acid pretreatment of maize stems retards enzymatic hydrolysis of cellulose. Biotechnology Progress, 23, 1333-1339.

Shenoy, D.; A. Pai; R.K. Vikas; H.S. Neeraja; J.S. Deeksha; C. Nayak \& C.V. Rao (2011). A study on bioethanol production from cashew apple pulp and coffee pulp waste. Biomass \& Bioenergy, 35, 4107-4111.

Sukumaran, R.K.; R.R. Singhanisa \& A. Pandey (2005). Microbial cellulases-production, applications and challenges. Journal of Scientific and Industrial Research, $64,832-844$.

Taherzadeh, M.J. \& K. Karimi (2007). EnzymeBased Hydrolysis Processes For Ethanol From Lignocellulosic Materials. Bioresources, 2, 707-738.

Wardhana, D.I. (2014). Produksi Gula Pereduksi dari Kulit Kapi Robusta dengan Metode Hidrolisis Asam. Jember: Jurusan Teknologi Hasil Pertanian, Universitas Jember. BSc Thesis.

Wyman, C.E.; B.E. Dale; R.T. Elander; M. Holtzapple; M.R. Ladisch \& Y.Y. Lee (2005). Coordinated development of leading biomass pretreatment technologies. Bioresource Technology, 96, 1959-1966.

Zhang, X.Z. \& Zhang Y.H.P. (2013). Cellulases: characteristics, sources, production, and applications. p. 131-145. In: S.T. Yang; H.A. El-Eshanty \& N. Thongchul. Bioprocessing Technologies in Biorefinery for Sustainable Production of Fuels, Chemicals, and Polymers, First Ed. John Wiley \& Sons Inc. 